\title{
The Tragic Hero of the Modern Period-The African Concept
}

\author{
Asuamah Adade-Yeboah ${ }^{1} \&$ Edward Owusu ${ }^{2}$ \\ ${ }^{1}$ Department of Communication Studies, Christian Service University College, Kumasi, Ghana \\ ${ }^{2}$ Department of Liberal \& General Studies, Sunyani Polytecnic, Sunyani, Ghana \\ Correspondence: Asuamah Adade-Yeboah, Address: Box 3110, Kumasi. E-mail: tonyviady@yahoo.com
}

Received: August 9, 2013 Accepted: September 13, 2013 Online Published: November 24, 2013

doi:10.5539/ells.v3n4p37 URL: http://dx.doi.org/10.5539/ells.v3n4p37

\begin{abstract}
There is an underlying cultural dimension in modern tragedy, in that the tragic hero differs from culture to culture in modern society. In the light of this, it is appropriate to point out that whereas the modern tragic hero in the Western culture is an anti-hero as portrayed in "The tragic hero of the modern period-The European Concept", in cultures such as, in Asia and Africa, the tragic hero still maintains some traits of the Greek heroic figure. This paper therefore fulfils an identified need to study the concept of this period's tragedy and shows the appendages of the traits of the Greek Classical tragic hero in the modern period of the African concept. The study provides extracts from Achebe's Things fall Apart as the main text, Achebe's Morning Yet on Creation Day, Achebe's Arrow of God and Rotimi's Kurunmi as supporting texts to present the African concept of the tragic hero.
\end{abstract}

Keywords: Okonkwo, African concept, thematic, tragic flaws, dual personality, pessimism, culture, tradition

\section{Introduction}

The archetype African tragic hero is part of oral literature. This means that the traditional tragic hero can be found only in oral literature. African tragedy has a cyclical structure, a reversible action and a community-oriented hero. To begin with, African cultures emphasize a belief in continuity of life extending from the ancestors through the living to the yet unborn. It means therefore that the practitioners of this type of culture believe in conjoint experience of life with their ancestors. In the light of this, misfortune can be averted from the path of the living and the yet-unborn, while sudden calamities can be demystified through divination. As the spectacle of tragic suffering is enacted, the African does not see tragic suffering as an isolated case of unrelieved suffering but sees it as a projection of an entire span, now tragic, now comic. It is in the light of this cyclical concept of tragedy that the African will "laugh at tragedy". This is because it is believed the very worst situation can turn into a pleasurable one.

Again, at the centre of the African concept of tragedy lies the belief in the reversal of the calamity. At the centre of reversing one's fate is the institution of divination. The concept is based on the assumption that through divination fate can be realigned. When one's fate or destiny is foretold, one is given a name that approximates that particular destiny. The significance of this divination is aptly illustrated in traditional folklore. In African folklore, it is said that a man is called by his maker to give an account of his life, which has been a life of plenty, ease and happiness. As he is about to die he calls a daughter to his bed. He dies and the daughter gives birth to a baby boy. A diviner advises that he is given a name 'Babalola', meaning "our father has returned". Hence we see the child as the father restored. Thus, the concept of tragic misfortune is not looked as a disgrace, but as a means to regeneration, and therefore the African is optimistic at the tragic situation. Wole Soyinka reiterates this in his discussion of Song of the Goat:

Storms do not occur every day nor are fishermen washed off their canoes on every fishing trip. But the hovering claims of this natural cycle dominate the natives' daily awareness, giving to rituals of appeasement an integrated essentiality for every event. Thus the death of an individual is not seen as an isolated incident in the life of one man. Nor is individual fertility separate from the regenerative promise of earth and sea. (1976, p. 51)

It has been suggested that there may not exist in Africa a tragic genre. Finnegan observes:

What dramatic or quasi-dramatic performance can be discovered never seem to involve tragedy in the 
normal sense. (1970, p. 516)

Even if African literature uses tragic features and episodes, African societies have been noted for the lack of sympathy for tragic situation. This is affirmed by Quartey. He says:

Most African audience watching drama characterize themselves by two different but related reaction; first, they participate in the action emphatically and persistently; second, they turn tragedy into comedy by laughing-laughing at tragedy. (1966, p. 102)

\section{Approach}

The study of African concept of tragedy cannot accommodate the European generic tradition. This is because modern African notion of tragedy, though distinct from the oral traditional concept of "laughing at tragedy", is thematically focused rather than generically based. Therefore this paper delves into selected prose, using the method of close reading which has been a recent approach in literary criticism, "where a critical analysis of the texts provides for the individual readers internalised literary devices" (McCaw 2008). Atkins (1993) reiterates the conception when he says, "every literary work is attended by a host of outside circumstances which, once we expose and explore them, suffuse it with additional meaning". To be able to delineate the tragic hero of this period, the content of the tragic situation will be focalised. The justification of this close reading approach is that, it brings influences to scholars with the view to examining "the ways in which text upheld the moral issues and codes of behaviour (and) "teach" readers about life and human nature". (McCaw (2008) as cited in Adade-Yeboah and Owusu 2013)

\section{Analysis and Discussion}

\subsection{The Modern African Writer and Tragedy}

The modern African writer has close links with the modern world. This situation makes it difficult for him to disentangle himself from the influences of Western literary forms and traditions. It is not surprising that writers like Soyinka, Ngugi and Achebe in attempting to rationalise African myths and legends in their tragic situations are inadvertently caught in the webs of Post-Classical Renaissance beliefs. Most African writers tend to conform to the Renaissance requirements that the tragic hero must be of eminent status like Macbeth and King Lear. The African tragic heroes like Okonkwo, Ezeulu and Amamu are indeed Renaissance heroes, Africanised.

\subsection{Heroic and Legendary Stature of Heroes}

From his rather humble beginnings, Okonkwo rises at the beginning of Things Fall Apart (1958) to become a prominent elder who is honoured with titles in the land of Umuofia. Similarly, Amamu, the hero of This Earth...My Brother (1971), is 'a been-to'; and Ezeulu, in Arrow of God (1986) is so outstandingly eminent that the colonial authorities have even considered making him a chief because he is a lover of his people. Again, Obatala in Ijemere's Imprisonment of Obatala (1966) is not only a leader of his people but his wrong doings have reverberations in the entire nation in the unnatural miscarriages of women, in plagues and drought as well as in various types of infertility in the land. Okonkwo satisfies the requirement of eminent status by virtue of his high social standing which is narrated in the opening lines of Achebe's Things Fall Apart:

Okonkiwo was well known throughout the nine villages and even beyond. His fame rested on solid personal achievement. As a young man of eighteen he had brought honour to his village by throwing Amanlize that cat. (1958, p. 1)

Thus, at an age when most young men would rather be idling within the homestead, Okonkwo has already become almost an equal of the ancestral heroes and gods. Ten years later, Okonkwo has risen by his own efforts to become the bread winner and general provider for his own wives and children, and for his aged father, Unoka, the failure. Indeed, so spectacular has Okonkwo's rise has been that within this short span of time he has become "a wealthy farmer and has two barns full of yams, who has just married his third wife". The description below of Okonkwo suggests his heroic and legendary stature:

Okonkwo's fame had grown like a bush fire in the harmattan. He was tall and huge, And his bushy eyebrows and wide nose gave him a very severe look. He breathed heavily, and it was said that, when he slept, his wives and children in their houses could hear his breath.

He has become such a trusted person that the society can count on him in times of trouble. For that reason, he is the one chosen to take the dreaded choice of war and peace to the people of Mbaino who have killed a citizen of Umuofia. By that same estimate, he becomes the obvious choice to take charge of Ikemefuna, one of the two reparations paid by the people of Mbaino. Like Okonkwo, Ezeulu in Arrow of God (1986) is prosperous, with a large household and highly placed in society and has achieved that rare honour of becoming a legend in his own 
life time. He is not just an ordinary person but he is also a spirit-medium. As the priest of Ulu, he does not have to prove himself. Everybody knows Ezeulu, "the hunch back more terrible than a leper".

\subsection{Fate and Character of the Hero}

The African tragic heroes have moral flaws and as such, they are responsible for their own downfall. The source of the tragic sufferings is the tragic flaw-character trait, even though fate may play a role in the tragedy of the hero. Things Fall Apart (1958) clearly illustrates the idea of fate and character. For example Unoka, Okonkwo's father, is a non-achiever partly because of his laziness and partly because of his fate. Achebe aptly puts it thus:

Unoka was an ill-fated man. He had a bad chi or personal god, and evil fortune followed him to the grave, or rather to his death, for he had no grave (p. 13)

Similarly, it would be seen from the account of Okonkwo's success that the individual will is superior to the dictates of fate:

At an early age he had achieved fame as the greatest wrestler in all the land. That was not luck. At most one could say that his chi or personal god was good. But the Ibo people have a proverb that when a man says yes his chi says yes also. Okonkwo said yes very strongly; so his chi agreed. (p. 19)

Yet, later, an accidental shooting brings to ruin all that Okonkwo has been building up:

His life had been ruled by a great passion to become one of the lords of the clan...Then everything had been broken. He had been cast out of his clan like a fish onto the dry, sandy beach, panting. (p. 92)

This reversal of events as seen from the above quotation is traceable to Okonkwo's own character trait. In Things Fall Apart (1958) Okonkwo's fear of failure serves as a spring board for which his tragic suffering springs. For example, Okonkwo, has always been guided by an inordinate passion to excel in order to avoid taking after his father's footsteps and becoming a loafer. This passion makes him act in a certain way. For example he tries to farm on a large scale at the mercy of the weather vegaries. Yet he is well aware of the uncertainties and repercussions of what he has done. This becomes expensive, for the harvest is poor. The behaviour of the hero is in conformity with his attempt to avoid failure and to become a successful man. The irony is that, try as he can, Okonkwo's actions rather draw him nearer to the much dreaded end.

Okonkwo's tragedy is also assessed on the grounds that in spite of the numerous titles and many achievements, he dies the same dishonoured death as the father he has always scorned. Okonkwo himself sums up his predicament after intense reflection:

Okonkwo's eyes were open and he saw the whole matter clearly. Living fire begets cold, impotent ash. (p. 102)

\subsection{The Tragic Conflict of the Hero}

When one is born with a particular trait of behaviour one is glued to that personality, clan, or lineage. Therefore one conforms to a dualistic pattern of life made up of one's own personal will and urge, and that which he inherits from his clan. It is this system of dual personality that creates conflict in the individual which also serves as the source of the tragic situation. Hegel (1962) therefore argues that 'African tragedy is typified by its enhanced individualism and egotism. He further asserts that "it must not be the case where two different ethical stand-points are juxtaposed but the personal-stand should be upheld". It is an interesting phenomenon to note that the pessimism and the deep sense of betrayal which characterises African tragic literature is quite rooted deeply in the destruction of traditional, cultural and economic systems. This happens when the protagonist either embarks on a more enlightened way of dealing with old issues or steadfastly adheres to the old traditions despite the advantages that a modification is likely to bring.

The individual stance degenerates at the micro-level into a confrontation with the rest of the community which ends in the demise of the individual and the triumph of the community. As a result of this, the African tragic hero is always characterised by an unyielding individualism. The two extreme positions thus created can be regarded as opposing ethical forces on a collision course. The tragic situation then is still the tragic flaw. Thus, the African concept of the tragic protagonist is merely a deviation from the main stream.

Unlike the Aristotelian type of tragic hero, the African tragic hero can see well before hand what will be in store for him. He can therefore take a decision to pursue his own course of action, and although the tragic hero must suffer for upholding a worthy cultural principle, yet this stand is against the traditional principle of the society. Hence the African tragic hero is a social impediment. The peculiarity about the African concept of tragedy here is that it is impossible for the tragic hero to be justified in any conflict with the society. Thus, Achebe's (1958) Okonkwo, as a tragic hero, is said to have erred because his pre occupations are with personal convictions. This 
may be so but then, these convictions are for the good of his fellow citizens. In his spectacular rise to grace, Okonkwo tends to symbolise the worthy ideals of his people:

Age was respected among his people, but achievement was revered.

In his military prowess, Okonkwolike Macbeth in Macbeth by Shakespeare (1958) is also representative:

He was a man of action; a man of war

Being so manly and so dignified, Okonkwo also becomes less humorous and cold, which is true to his image of a man of valour.

Okonkwo never showed any emotion openly, unless it be the emotion of anger. To show affection was a sign of weakness. (p. 30)

\subsection{Moral Flaws}

If these virtues of Okonkwo are the basis for praising him, one may wonder why he dies a shameful death and is rejected by his own people? Okonkwo like Lear and Kurunmi has a moral flaw. This is rooted in his pride and obstinacy, as well as his tenacious adherence to tradition as practised by his forefathers. Given the choice, he rejects peace and chooses war as a means of asserting his personal convictions, and uncompromising stand on the issue of Christianity in the society, specifically at the period the white man comes to Africa as missionary, trader and administrator. This period undermines traditional beliefs and practices. W.B. Yeats' poem:

"Things fall Apart: the centre cannot hold.Mere anarchy is loosed upon the world".

This awareness of things falling apart is understood by Obierika in his accusation of the white man.

"Now he has won our brothers and our clan can no longer act like one. He has put a knife on the things that held us together and we have fallen apart" (p. 124)

The story of Things Fall Apart (1958) is therefore the tragedy of Okonkwo, an important man in the tribe in the Ibo society of Nigeria. Achebe's simple but excellent novel tells of the series of events which lead to Okonkwo's exile from his own tribe and his return only to be forced to the ignominy of suicide to escape the results of his rash decision against the white man. He handles the macabre with telling restraint and the pathetic without any false embarrassment. In his book Morning Yet on Creation Day (1976), Achebe upholds the belief that there is existence of uniformity of cultures:

Most African writers write out of an African experience and of a commitment to an African destiny. For them that destiny does not include a future European destiny. (p. 20)

\subsection{Okonkwo's Tragic Source}

Okonkwo, the tragic hero, is seen to have acted through principle rather than sheer wickedness. The tragic source of the hero must be from his sense of guilt. Like the Renaissance hero, Okonkwo's tragic source is his emotions. It is in the light of this that Okonkwo's punishment meted out to him on the occasion of his accidental shooting of his kinsman, is said to be unfortunate. One cannot but feel that Okonkwo has many a time been circumspect in his reaction to situations.

Similarly, in Arrow of God (1986), Achebe traces the fate of the proud and dedicated chief priest, Ezeulu, who defies his clan and the white man. He is misunderstood by his own people in his attitude to the colonial administration, which does not allow for any understanding of Ezeulu's position as a religious leader. His refusal to accept the post of "chief" is taken as an insult. The novel thus shows the tragedy of a man destroyed by powers beyond his understanding. In the instances shown above, we can deduce that the actions of the protagonist are in themselves void of any malice and self gain, yet the element of circumspection is held against him and this is his tragic source. These heroes have created their own situations and once they take the unilateral decision, it leads to its logical conclusion.

Okonkwo's fear-motivated career leads him to the extremes. In his desire to become a man among Ibo men of titles, he has acquired an exaggerated idea of manliness. He deliberately suppresses any feeling that might betray his humanness for the simple reason that, for him, to be a man is to be tough. Okonkwo's desire to be nothing else but the strong man of society is deceptive in itself. In his obsession he ignores the fact that a man does have fine feeling; that a show of coarse feelings does not in the end make a man, but a beast.

Furthermore, Okonkwo's prosperity makes him a bully and an arrogant man, treating less successful men with contempt. For example, at a clan meeting to discuss the next ancestral feast, a man without a title contradicts Okonkwo and Okonkwo calls him "a woman". We can quickly deduce from his reaction that Okonkwo sees the image of Unoka, his father, in every unsuccessful man. Achebe clearly states this: 
He had no patience with unsuccessful men. He had no patience with his father. (p. 3)

\subsection{Okonkwo's Tragic Situation}

It is for this same reason that Okonkwo breathes rather heavily down Nwoye's neck whenever the latter exhibits what Okonkwo regards as "feminine" or Unoka tendencies. Okonkwo is described as "man of action". However, unlike Ezeulu in Arrow of God (1986) most of his actions are a far cry from Ezeulu's good manners. Besides being an individual, Okonkwo is also an embodiment of the stubborn conservative element of the Ibo personality. $\mathrm{He}$ is portrayed as a symbol of the warrior spirit of the traditional Ibo society and a vector of the cultural values of that society. Yet there is still something of an irony in the relationship between Okonkwo and his people. While embodying the values of the society, he is in constant conflict with the same society because of some of his actions which negate the very values that he himself embodies. The banishment of Okonkwo for an inadvertent killing of the sixteen-year old boy duing a funeral rite shakes his confidence. He leaves behind the Umufia that he knows best, and goes to live amongst his mother's clan at Mbanta. This banishment also coincides with Okonkwo's rise in wealth and fame. This is a tragic situation which is a turning point in the life of Okonkwo.

Okonkwo's fury is so strong a character trait that, his fury dictates his action. For example, while in exile at Mbanta, he hears of the arrival of the missionaries. Okeke's suggestion that the best course to take is to ignore the missionaries does not go well with Okonkwo. He thinks otherwise. He thinks that the missionaries are being sacrilegious and Okeke's suggestion is nothing short of cowardice. He says:

"Let us not reason like ... cowards. If a man comes into my hut and defecates on the floor; what do I do?

Do I shut my eyes? No! I take a stick and break his head. That is what a man does" (p. 113)

\subsection{Okonkwo's Resistance to the Tidal Waves of Christianity}

At this point Okonkwo does not know that the white-man is encroaching on Umuofia territory in the same way. But what we ought to remember is that in an alien clan, Okonkwo cannot act in the same way as he would back home. Even though it can be argued that Okonkwo does not have the leeway to act as he would wish to in a strange clan, the tough worded reaction quoted above illustrates his opposition to foreign influence in Iboland. He puts up a spirited resistance verbally against the tidal waves of Christianity, even when they are seen to have become inevitable; inevitable because while an individual can stay away from the Christian gatherings that have become an establishment, it does not seem likely any more that any one individual will be able to prevent Christianity from influencing the society as a whole. The worse of Okonkwo's tragic suffering occurs when his own son, Nwoye deserts home to join the religion that has caught many people like a fever. This piece of news further exposes Okonkwo's fury as he contemplates revenge.

A sudden fury rose within him and he felt a strong desire to take up his matchet to go to the church and wipe out the entire miscreant gang. (p. 108)

On his return to his fatherland, he is deeply grieved and mourns for the clan which he sees breaking up and falling apart. He sees the men of Umuofia as men who have unaccountably become "soft like women". He calls for action, for, he believes there is still time to do something to steer the clan away from irrevocable disaster. Despite all indications that the historical currents of change must prevail, Okonkwo refuses to acknowledge the forces at play to change Umuofia. He therefore vows that if the clan will not rise up against the alien culture in defence of its own pride, then he the proud Ibo warrior, will salvage his clan all alone. This is clearly shown by Achebe's description of Okonkwo's mental torments:

"As he lay on his bamboo bed he thought about the treatment he had received in the white man's court, and swore vengeance. If Umuofia decided on war, all would be well. But if they chose to be cowards he would go out and avenge himself" (p. 141)

Unlike Ezeulu in Arrow of God (1986), Okonkwo's resilience is not founded on any well thought-out principles. It seems to spring from the same fear that has dogged him all his life-the fear of being thought weak. He must be seen as a man; and for him the essence of manliness is not to give in an inch.

Okonkwo cannot stand trechery. He wonders why the Umuofia which was feared by all neighbours, so powerful in war and in magic is now a shadow of its former self, giving into the foreign culture. The clan again blames him for killing the white man in his attempt to fight against foreign domination. Okonkwo thinks he is a victim of betrayal by his people and therefore prefers to die. The irony is that while avoiding the shameful death by hanging in the hands of the white man, Okonkwo dies a more shameful death. Although he has succeeded in living a dignified life, all that dignity has been drained down the gutter by his shameful death. 


\subsection{Error of Judgment}

One significant action, perhaps an error of judgment of Okonkwo's is taking part in Ikemfina'a sacrifice to the gods of the land. This action affects him greatly. Drunkenness or hard work will not help him in any way to get over these mental torments. From this point on, we see Okonkwo touched by remorse resulting in his refusal to eat for two days. This is actually a trait which is contrary to what Okonkwo stands for, a clear indication of a tragic situation as a result of wrongful act.

During the season of the Week of Peace when the entire community is religiously enjoined to observe the peace, Okonkwo achieves the unique notoriety of being the first person ever to break the peace by beating his youngest wife so fiercely that people rush out in great commotion to the scene. As a result, Okonkwo is chastised by the authorities. As Achebe puts it, "The evil you have done can ruin the whole clan". This warning from the priest of the Earth goddess, Ani, sounds ominous. By his conduct he disrupts the traditional good will, which is also one of his tragic sufferings in the novel. Okonkwo's character has been moulded by his environment. At every single point in the narration, Achebe tries to relate every belief, every activity of his society to some aspect of Okonwo's character. Stated differently, the development of Okonkwo's character and the presentation of his society are related. Okonkwo is a man of power and substance. He reverses his family, ancestors and gods and unquestioningly upholds the laws of the tribe. He sees the gradual decay of all he holds most valuable, a decline hastened by the arrival of the Whiteman. Even though Okonkwo rules his household with a heavy hand, deep down in his hearts, he is not wicked but his whole life is dominated by fear, the fear of failure and of weakness.

\section{Strict Adherence of Heroes to Tradition}

As a traditionalist, Okonkwo is understandably very religious and observes all rites and rituals prescribed for the proper maintenance of ancestral shrines. It is in the light of this that he joins in killing Ikemefuna. This trait underlines the African tragic protagonist's unqualified faith in his gods, especially when he believes himself to be in the right.

In Ola Rotimi's Kurunmi (1971), Kurunmi, like Okonkwo, is a traditionalist. Thus he is constantly seen in the play asking for guidance and imploring for support from both the gods and the ancestors. In the play, we are presented with the reigning monarch of the Yoruba kingdom of Oyo, AlafinAtiba who suggests that his eldest son Adelu, succeeds him instead of having him follow him to his grave as tradition demands. Kurunmi finds this as an insult to the traditional values of his society and therefore opposes it vehemently. The tragic situation is that the leaders of Ibadan accept AlafinAtiba's proposition as a forward-looking innovation, a move which will strengthen the new Oyo kingdom. This leaves Kurunmi stranded since there is a betrayal of the stand he has taken. With the unflinching support of the Ibadan leaders Adelu is crowned on his father's death.

The beginning of trouble is when Kurunmi refuses to attend Adelu's coronation. Naturally, AlafinAdelu tries to find out from Kurunmi by sending a messenger with two symbolic alternatives from which Kurunmi is to choose and thus declare his stand. Either he is to accept him as a ruler and agree to a peaceful co-existence or to reject his installation and accept the challenge for war against the rest of the Oyo kingdom. The answer Kurunmi gives rather aggravates the situation and it clearly reveals his arrogance. He maintains his stand for tradition and therefore chooses war. He does not end it there but caps it with an incredibly rude and contemptuous gesture by sending the new Alafin a soiled napkin. Kurunmi's stand is that:

...what is a man without knowledge of himself? We have traditions, the sacred law of the people left by our fathers to guide our lives. Adelu now lives on after his father-a mockery of tradition. Adelu in the aged face of tradition. (Kurunmi. 1. iii)

This is a significant statement which sums up the stand of Are-Ona-Kakanfo Kurunmi hence the tragic situation resulting in the war he fights which he never should have attempted. The irony of the matter here is that even through Kurunmi insists on upholding tradition by refusing to accept AlafinAdelu as ruler, he at the same time breaks tradition by not consulting his state to go to war-a war which is tantamount to a rebellion. His immediate deputies, Ogunkoroju and AreagoruAjayi, make this point clearly in showing their displeasure. They rightly feel that: "The land is not quite ready for war". Despite their displeasure they show loyalty by pledging to stand firm beside their leader. It means they are prepared to fight the war, the war which is to bring untold and profound tragic repercussions. Kurunmi is fully aware that the reply and the action he has taken will bring nothing but war in its wake. He therefore sets about consolidating alliance with his neighbours who are not of the Oyo Kingdom. This behaviour of Kurunmi in itself is a defeatist course of action Kurunmi takes. His people have rejected him and his actions.

The Egbas whose services Kurunmi employs for the war are the very people who cause his defeat inadvertently. 
The commander of the Egba force insists on crossing the Oseriver in pursuit of the Ibadan forces but Kurunmi thinks otherwise. Kurunmi considering the Egba force alliance as vital to his success complies against his wishes. As the allied forces cross the river, much to the surprise and pleasure of the Ibadan forces, their retreat is blocked and they are defeated soundly in the war. Clearly, we see Kurunmi's vulnerability. He easily gives in to the commander's suggestion without a careful analysis of his decisions.

Like Okonkwo, Kurunmi is egocentric. He pursues distinction with an obsessive single-mindedness. His personal disposition and reaction to social and traditional upliftment stemming from a subjective perception prepare his fate. The suicide which both Okonkwo and Kurunmi commit is a gesture that symbolises the same time their personal refusal of a new order, as well as the collapse of the old order which they represent. The inflexibility is their tragic flaw. "The old order changeth yielding place to new". Okonkkwo, like Kurunmi is not flexible about this state of change so he shows an aversion to it. Kurunmi's personal failure also becomes the failure and demise of his subject. The tragic loss of lives during the war is phenomenal and Kurunmi does not have the courage to face his subjects again.

\subsection{The Demise of the Tragic Heroes and the Triumph of Society}

Okonkwo's way of shutting everything out of his view save he indicates that his ambition has become a blinding passion of a pathetic kind. He is too rigid, and his insistence on things is such that he becomes a menace to his society. Okonkwo's strong resolve that he must be a man of valour, makes him harden himself against ordinary human beings, so that he becomes dehumanised. His revengeful nature is seen in his involvement in the killing of the messenger of the colonial administration. He has therefore become a misfit in the changing society and his final removal is beneficial because he constitutes an impediment in the way of peaceful evolution.

Kurunmi, very much like Okonkwo, Amaamu and Ezeulu, the tragic protagonist's takes his lone stand against the rest of the community and maintains it to its logical end. This leads to his own demise and that of his followers but it leads to the triumph of the society. It is also the defeat of an archaic custom and the victory for the new and changing order. Thus, Kurunmi's death much like Okonkwo's, becomes a victory for the forces of change. The basic condition of the heroes, Okonkwo, Kurunmi and Ezeuku is the desire to do what they like rather than what the society demands that they must do. For example Okonkwo wants to marry a girl of his own choice rather than of his mother's. Another example is Amamu who wants to live his own life rather than living a life of a typical "been-to". For him, the symbol of his independence and his individualism is his guitar. Amaamu wants to keep the company that his status imposes. He renounces his social class and privileges, abandons his comfortable home and occupation, and moves back to the slums of Nima to live with his girlfriend. By desiring their own way, such African tragic heroes in effect try to distance themselves from the larger community.

The tragic situation in terms of the African writer is thematic rather than generic. Okonkwo in Achebe's Things Fall Apart (1958) playing exactly the same role as the tragic heroes of a drama, reaches the same end despite the fact that Okonkwo is a hero of a novel and Kurunmi is a hero of a play.

\subsection{The Tragic Conception in Perspective}

The intellectual achievements of the Greek claim our attention not only for their sake, but also because they have helped in shaping our looks and tastes for all Western Civilization. A 'hero' in the technical Greek sense is not merely the principal figure in a work of art but one whose career has somehow enlarged the horizons of what is possible for humanity and who has therefore, after his death, been deemed worthy to be remembered. It is in the light of this that there are tragic heroes in the works of Sophocles, Shakespeare, Racine, Beckett and Achebe. But it must quickly be remarked that each of these heroes is completely different from each other. The reasons for this metamorphosis of the tragic hero are not far to seek.

\subsubsection{Classical Period}

In the first place metamorphosis is as a result of cultural differences. The culture of the Greeks is brought to bear on their conception of tragedy. Greek tragedy offers the most significant approach to their spiritual contributions because tragedy combines high art with profound thought and because drama is a form generally familiar. For example, Greek drama grew out of the religious ritual and was presented as part of religious activity. The plays presented were at the Dionysian festivals. The subject matter was based on myths already in existence. Hence the best plays were those presented in such a way as to give the most pleasure or perhaps the best catharsis. This religious association also controlled the structure of the play, and the mode of presentation. The Greek pagan belief in instant retribution gave rise to the atmosphere of gloom and despair which characterised the Greek tragic hero. 


\subsubsection{Post-Classical Renaissance}

Preceding the Greek culture is the one based on and represented by Shakespeare's tragic hero. Shakespeare characteristically blends elements of British mythology, medieval Feudalism, and Renaissance benevolent despotism to create a composite image of an older order which exists in the mystic communion with God and with the order of the cosmos.

\subsubsection{Neo-Classical Revival}

Racine's Jasenist worldview of Jansenism makes him a strict adherent of morality. Besides, Racine believes in 'bienseance' which is born out of the French Neo-Classical tradition hence his heroes are seen to act in conformity with the period. This period seems to reach its ultimate dramatic achievements and makes us see the human condition as being tragic from the way Racine portrays his heroes.

\subsubsection{The European Concept}

The cultural background of the modern period no doubt reveals a different type of heroes. For example, the $20^{\text {th }}$ century European heroes can be traced to the anxiety of the time which is traceable to the decadence in modern life. The period presents complexities. It is therefore not surprising to see that the heroes of this period are anti-heroes whose traits and characteristic cannot easily be focalised.

\subsubsection{The African Concept}

Culturally, the modern African tragic hero is uniquely different from the Western hero. The African does not see tragic misfortune as a disgrace but rather as a means to regeneration. For this reason heroes are portrayed to be optimistic in their tragic suffering. However, they are portrayed as having moral flaws and therefore responsible for their own fall. The modern African tragic hero conforms to a dualistic pattern of life which creates a conflict in him and this serves as his tragic situation.

\section{Conclusion}

A study of the tragic conception clearly reveals that the whole tragic tradition from the time of the Greeks to the present, has undergone a metamorphosis. Writers and philosophers alike have sought to relate postulates of tragedy as a concept that explains and justifies the problems and woes of life. Even though there have been changes over the centuries in the concept of this tragic genre, its essence remains the same. In the diversity of the tragic conceptions there is also continuity.

It is also observed that the movement from one period to another has a corresponding period. For example, the Greek classical tragic hero is differently portrayed from the tragic hero of the Post-Classical Renaissance. Similarly the anti-hero of the $20^{\text {th }}$ century is another type of hero of this period. The modern African concept also presents tragic hero whose tragic misfortune is not seen as a disgrace, but as a means to regeneration. Modern tragedy therefore becomes a matter of psychological mutation, where the tragic experience is interiorised.

Ultimately, the chief reason for the metamorphosis of the tragic hero goes back to the Renaissance. Christian Europe in the $15^{\text {th }}$ and $16^{\text {th }}$ centuries did not appreciate the pagan current underlying the Aristotelian conception of tragedy and the career of its hero. In the pagan mind, a good man can commit evil if he is fated to, and even against his purest desires. Doing wrong to the Greek mind did not depend on one's character but often on the unsteady will of the gods. The pagan "hamartia", therefore was the crucial distinction between the Greek hero and the post-classical hero. To the Greeks, hamartia is an act of sacrilege committed unwittingly irrespective of the hero's good nature. To the Renaissance and beyond, hamartia is a tragic flaw which is a weakness in an otherwise solid disposition. Herein lies the difference between the Greek tragic hero and his successors.

Tragedy as a tradition has been problematic in terms of definition because of the shift in the nature of the tragic hero. But this does not undermine the authentic posture of the tragic tradition. The fact that pain and suffering give pleasure is a paradox. Nevertheless, this paradox is explained by the fact that this aesthetic experience is achieved through the beauty and excellence generated by the work of art rather than by the subject matter. Stated differently, tragedy is indeed an exciting subject. Despite the possibility that the denouement (the untying of the knot) may not always bring satisfaction to the audience, it certainly generates a lively human sympathy. The essential point is that tragedy relates to the person of the hero. This emphasis on the individual has since become one of the essential elements of Western tragedy.

\section{References}

Achebe, C. (1958). Things Fall Apart. London: Heinemann.

Achebe, C. (1976). Morning Yet on Creation Day. London: Heinemann. 
Achebe, C. (1986). Arrow of God. London: Heinemann.

Adade-Yeboah, A., \& Owusu, E. (2013). The Tragic Hero of the Modern Period-The European Concept: Studies in Literature and Language, 6(3), 33-38. http://dx.doi.org/10.3968/j.su.1923156320130603.5263

Atkins, D. G. (1983). Reading deconstruction. Deconstructing Reading. Lexington: University press of Kentuckey.

Awonoor, K. (1971). This Earth, My Brother. Garden City: Doubledy.

Finnegan, R. (1970). Oral Literature in Africa. Oxford: University Press.

McCaw, N. (2008). How to Read Texts: A Student Guide to Critical Approaches and Skills. London: Continuum.

Obotunde, I. (1966). Imprisonment of Obatala. London: Heinemann.

Rotimi, R. (1971). Kurunmi. Ibadan: University Press Ltd.

Shakespeare, W. (1958). Macbeth. In The Complete Works of Shakespeare. New York: The Chaucer Press Ltd.

Sonyinka, W. (1976). Myth Literature and African World. Cambridge: The University Press.

\section{Copyrights}

Copyright for this article is retained by the author(s), with first publication rights granted to the journal.

This is an open-access article distributed under the terms and conditions of the Creative Commons Attribution license (http://creativecommons.org/licenses/by/3.0/). 